\title{
The Impact of the Personality Traits of an Actor on Their Position in the Social Network: A Study on Public Employees
}

\author{
Pınar FAYGANOĞLU iD a \\ a MSÜ-Kara Harp Okulu, İşletme ve Yönetim Bilimleri Bölümü, Ankara, Türkiye. pfayganoglu@kho.msu.edu.tr
}

\begin{tabular}{|c|c|}
\hline ARTICLE INFO & ABSTRACT \\
\hline $\begin{array}{l}\text { Keywords: } \\
\text { Social Network Theory } \\
\text { Machiavellianism }\end{array}$ & $\begin{array}{l}\text { Purpose - The aim of this research is examining whether the personality traits of the actors within a given } \\
\text { social network have an impact on their partaking as central actors in the network and maintaining their } \\
\text { brokerage role between the actors who do not have a connection. }\end{array}$ \\
\hline $\begin{array}{l}\text { Received } 9 \text { October } 2021 \\
\text { Revised } 10 \text { November } 2021 \\
\text { Accepted } 10 \text { December } 2021\end{array}$ & $\begin{array}{l}\text { Design/methodology/approach - The network sample of the research consists of } 73 \text { individuals that } \\
\text { worked in the same unit of a public institution located in Ankara. In order to make social network } \\
\text { analysis, the answers obtained from the questions asked to the actors were transferred to the UCINET } \\
\text { program by creating a } 73^{*} 73 \text { matrix, and betweenness, centrality and network diagram analyzes were } \\
\text { made. Then, the values obtained from the questionnaires made in order to determine the personality traits } \\
\text { of the actors were entered into the SPSS } 20 \text { package program. Finally, within the scope of the analysis of } \\
\text { the study, correlation and regression analyzes were carried out to determine whether there is a } \\
\text { relationship between the data obtained from social network and personality traits. }\end{array}$ \\
\hline \multirow{2}{*}{$\begin{array}{l}\text { Article Classification: } \\
\text { Research Article }\end{array}$} & $\begin{array}{l}\text { Findings - As a result of the analyses, the actors who has a high level of Machiavellian and neurotic } \\
\text { personality traits fill the gaps within the social network and assume the role of a bridge / a broker. It is } \\
\text { also founded that there is a negative relationship between the actor's neurotic personality traits and their } \\
\text { centrality positions within the network. On the other hand, the actor's with high agreeableness personality } \\
\text { trait are observed to be positioned at the center within the network. }\end{array}$ \\
\hline & $\begin{array}{l}\text { Discassion - The absence of a study in the literature that deals with social network connections and } \\
\text { personality traits together reveals the originality of the study. }\end{array}$ \\
\hline
\end{tabular}

\section{Introduction}

It can be argued that the personality traits of the individuals that are members of an organization are influential in many areas when speaking organizationally. Accordingly, the organizational research literature argues that the personality traits of the individuals impact themselves within contexts such as risk taking behavior (Nicholson et al.,2005; Kogan and Wallach, 1964; Zuckerman and Kuhlman, 2000; Levenson, 1990), personal performance (Blickle, 1996; Paunonen and Ashton, 2013; Ashton, 1998), job stress (Parkes, 1994), subjective well-being (DeNeve and Cooper, 1998; Diener et al., 1999; 2002; Furnham and Cheng, 1997; Lu and Hu, 2005; McCrae and Costa, 1991). It can be argued that the said area of influence extends to the social relationships, which has been an unavoidable fact everywhere / in every area that individuals existed in since they started living in communities, and even to the social networks that emerge as a natural consequence of such relationships. And also, the position of an individual in a network where the individual is an actor is another state that is again affected by the personality traits of the individual. In other words, in order to keep the organizational outputs at the highest level, the organization has to know the employee behaviors closely. Within this framework, it can be said that the central location of the personality traits of an individual within a network that the actor is present can fill the structural gaps within the network and impact the role of brokerage, which refers to being a bridge between such gaps. It is considered that the actor, who is in the center in the social network can hold some power elements because he has more network connections than the others. Likewise, actors in brokerage position who establish a connection between the actors who are not related to each other within the social network are also extremely critical personnel for the organization. In the management and organizational research literature, it is stated that the studies that empirically determine 
the elements that have an impact on especially the network structures formed by the individuals and the individuals' positions within the networks are relatively fewer (Klein et al., 2004).

The purpose of this study is to determine whether there is a relationship between the personality traits of an individual and their position within a social network that they are a member of. In other words, the purpose of this study is to establish whether the personality traits of an individual have a relationship with the centrality or brokerage role of the actor in a network structure that the actor is a member of. In this context, the Machiavellian personality attitudes and the Big Five Personality Model (BFPM) is to be utilized in order to determine the personality traits of individuals. The positions of the individuals within the social network and the benefits they acquire through this are explained within the framework of social network theory, and the analyses are carried out through the social network measurements. Although the sample of the work seemingly low in number, it is derived from the specification characteristic of the network researches. Accordingly, in the network analysis studies, the samples have to contain all the actors of the chosen one and be restricted with the numbers of actors within that network. So, the sample of the research consists of 73 individuals that worked in the same unit of a public institution located in Ankara.

\section{Theoretical Framework}

\subsection{Social Network Approach}

The concept of social capital, which can be defined as the utilization of the social relationships emerging between the individuals for the goals of the actors, is in fact comprised of many definitions and dimensions such as social concepts. Within this framework, the concept essentially refers to all the advantages acquired by the individual due to the individual's position in a relationship network (Burt, 2005). In the management and organizational research literature, it is stated that there are four important network approaches formed as a consequence of social capital, and these are weak ties, strong ties, closed networks and structural gaps.

Weak Ties refer to the achievements acquired through the interactions that occur in relatively smaller frequency between the actors (Granovetter, 1973). The theory argues that the weak ties, which does not have to have a social nature between the actors within a network and which are seen as weak bonds developed at arm's length, can provide the actors various benefits (Granovetter, 1983). According to this, it is stated that the relationships developed between the actors in time and in sporadic intervals can be accepted as weak ties. It is also stated that the information acquired by the actor from professional and managerial employees regarding a new work can only be acquired through weak ties (Granovetter, 1983).

On the other hand, the Strong Ties approach argues that the strong ties can essentially provide more benefits to the actor(s) within a network instead of weak ties (Bourdieu, 1986). In other words, the strong ties argue that the relationship between the actors within a network structure is based on trust and constant interaction (Podolny, 2001; Coleman, 1988). It is stated that the actors within a network structure have a tendency to form their relationships always on strong ties and direct their efforts towards this goal (Gulati and Gargulio, 1999). It is argued that the access for intra-organization information between the actors that are connected to each other through strong ties in a network structure based on data, and as a consequence of this, access for the resources become relatively easier for the actors (Coleman, 1988). Accordingly, the higher number of relationships that have strong ties within a network refers to the easier circulation of communication and information within the said network and thus reduction of uncertainties (Kraatz, 1998). It is also said that the entry to network is kept under control in networks that possess strong ties since the same network has solid trust and firm bonds.

On the other hand, Closed Networks provides implications for the strong relationships of the actors that are limited within their own networks during the social interactions (Coleman, 1988: 105). It is stated in the literature that alongside their intense internal control elements, the closed networks have a restrictive effect on the actors that are members of the network. However, the intense and close interactions developed between the actors within a closed network structure and the high level of trust, communication and performance as a natural consequence of these interactions are regarded as the advantages provided by the network (Kraatz, 1998). In addition to these advantages, Coleman (1988) states that the high level of trust that emerge as a result of intense relationships developed within a closed network structure plays an active role in the rapid and easy solution of the problems that may occur between the members of the network. 
Another approach that is put forth regarding the network structure is suggested by Burt (2005) and refers to the 'structural gaps and brokerage roles' regarding the brokerage activities of the actors that fill the structural gaps between the network structures. The theory argues that there are structural gaps between the actors that do not have connection to each other within a network structure, and that there are 'brokers' who assume the role of a bridge between such gaps (Burt, 2010). The said brokers or actors that assume the role of brokerage are said to comprise the information and resource transmission between the other actors that do not have any connection between them (Burt, 2004). In this context, it is stated that the actor(s) that assume the role of a bridge by filling the structural gaps within a network structure based on data possess the critical information that circulate within the organization/network and keep a hold of the advantage to utilize such information (Burt, 2004; 2005). In this context, it is stated that the broker actor is relatively ahead of others in terms of accessing the information and acquiring some advantages for the benefit of themselves or the organization when compared to the other actors within the network (Gargiuli and Benassi, 2000). On the issue of other actors remaining silent regarding the aforesaid state, Burt (2010) has stated that both parties that create the structural gaps are in fact not that independent from each other and they are unaware of the other party as they are very much occupied by their own works. It is stated that the fact that the broker actor maintains and controls the information is true for both parties that create the structural gap, and the role of broker provides the actor the advantage of information and control (Burt et. al, 1998). According to this, the advantage of information can be referred to as the actor having more information that they would normally be able to acquire, learning the news before everybody else, and the opportunity for the actor to utilize the information they acquired at a time and in a manner they desire so; and the advantage of control can be referred to as the ability to keep the information that is to be transmitted to other actors under control, and ability to utilize the opportunities. Burt (2004) has stated that there are four different levels regarding the brokerage levels of the actors. The first of these levels is the simple brokerage that refer to the information transmission between the two parties that create the structural gap within a network structure; the second is the high level of brokerage through which only the useful / important information is transmitted between both parties; the third is the brokerage that transmits the similarities between the groups that from the structural gap in order to create a difference; and the fourth and final one is the brokerage that creates new information by combining the newer information that it acquired between the groups that create the structural gap.

In addition to the abovementioned approaches regarding the network structures, it is also emphasized that the relationship that an actor has within a network structure based on data and the type of that relationship is also very important, and 'Centrality' is one such relationship (Sözen and Gürbüz, 2012). According to this, the said concept refers to the position of an actor within a network structure, and it is determined according to the number of relationships an actor has within a network (Kim et al., 2011). In other words, we can say that the actors that have the highest number of network relationships are accepted as the central actors by examining the relationships of actor(s) with others within a network structure. In the literature, it is also stated that the actors at a central location within a network structure would have certain advantages over the others. According to this, it is emphasized that since the central actor has a higher number of connections when compared to the other actors within the network, the central actor may have some opportunities such as accessing critical information or accessing organizational / personal resources more rapidly and easily when compared to the others (Hagedoorn, et al, 2006). In a similar manner, it is cited that the centrally located actor within a network structure is perceived to be more trustworthy and stronger when compared to the other member as the actor is located at the center, and therefore, the other actors that are especially located at the periphery of the network may feel a certain level of dependency to the central actor (Sargut, 2006).

\subsection{Personality Traits}

\subsubsection{Machiavellian personality attitudes}

The behavior of the individuals, who are members of an organization, within an organization and the interpretation of such behavior appears before us as a very important phenomenon within the period since the acceptance of organizations as social entities. When the management and organizational research from past to present is examined in order to reveal and interpret the abovementioned situation, it can be said that personality traits are one of the most important characteristics that affect the behaviors and attitudes of individuals concerning, for instance, the intra-organization power (Roberts et al., 2007; Karkoulian et al., 2009; Grams and Rogers, 1990; Erkuş, 2010), justice (Henle, 2005; Shi et al., 2009; Elovainio et al., 2003), team / group 
work (Forrester and Tashchian, 2010; Hoffman, 1959; O'Neill and Kline, 2008; Colbert et al., 2014), performance (Peterson et al., 2003; Sikalieh and Mkoji, 2012; Shih et al., 2009; Yelboğa, 2006), work satisfaction (NewburyBirch and Kamali, 2001; Judge et al., 2000; Morrison, 1997; Furnham et al., 2009; Mount et al., 2006) or organizational loyalty (Erdheim et al., 2006; Srivastava, 2013; Farrukh et al., 2017; Kell and Motowidlo, 2012) .

It can be said that there are many studies and models in the literature that can help identify the personality traits of the individuals, and the following examples can be given for such studies and models: the big five personality traits that is comprised of sub-dimensions of agreeableness, extraversion, neuroticism, conscientiousness and openness to improvement that systematically handles the relationship between the personality traits of an individual and their behaviors (Montag and Levin, 1994; Goldberg, 1990; Costa and McCrae, 1995; Coolidge et al., 1994); type A personality traits that refer to those who are competitive, focused on work and success, mainly aggressive, stressed and directed towards time and the type B personality traits that are the opposite of type A (individuals with extremely low level of competitiveness, who cannot focus on work very much, who are accommodating and relaxed) (Lelord and Andre, 1996; Robbins, 1999); and the Machiavellian personality attitudes, or in other words, Machiavellianism that describes the individuals that are prone to use whichever means necessary to attain their goals (Christie and Geis, 1970, 2013; Jones and Paulhus, 2009; Geis and Moon, 1981).

Christie and Geis (1970), who has contributed the concept of Machiavellianism to the relevant literature, state that the Machiavellian personality attitude/tendency is a personal difference (Diener et. al., 1999). It can be seen that there are different definitions regarding the Machiavellian personality attitudes in the management and organizational research. According to O'Connor and Athota (2013), Machiavellianism is defined as a personality trait that is shaped through exploitative and manipulative behaviors, that holds the personal gains the highest, and that can manipulate and use other individuals to achieve their own goals. In a similar manner, McHoskey and his colleagues (1998) define the Machiavellian attitudes as the individual being pragmatic and using whichever means necessary to attain their own goals. Another definition suggested for Machiavellianism is that the individuals may not refrain from trying certain methods (power, politics, etc.) in order to attain the goals / interests that they essentially desire, and while trying those methods, they may not refrain from directing / manipulating others (Jones and Paulhus, 2009; Quick vd., 1997). Solar and Bruehl (1971) argue that the effort made by those individuals with Machiavellian personality traits in order to appear as perfect and flawless is not because they hold the power but instead because they are powerless. According to another definition in the literature, Machiavellianism is comprised of unethical behaviors (Guterman, 1970).

When the definitions in the literature are examined, it can be said that the individuals with Machiavellian personality traits are described as individuals that commonly resort to cheating in order to achieve their personal goals; that direct individuals and/or hide the truth from individuals in order to direct them towards their personal goals; that can easily manipulate other individuals before them; and that are non-empathetic. In addition to these, the individuals with high Machiavellian personality traits are said to be individuals that are only focused on goals, power and success, that approach incidents calmly rather than emotionally, that are deceivers, opportunists, selfish, and that give importance to efficiency (Christie and Geis, 1970; Roberts et al., 1998; Fehr et al., 1992; Jones and Paulhus 2009; Kessler et al.., 2010). It can be said that the common point of the abovementioned traits is the tendency of the individuals that exhibit Machiavellian personality traits to display a social behavior pattern that is manipulative of others for the benefit of themselves, and it is emphasized that there are individuals with Machiavellian personality traits in every social structure that the individual is included / lives in (Wakefield, 2008).

The study, in which Christie and Geis (1970) contributed the concept of Machiavellian personality to the literature, states that there are four different dimensions regarding the manipulation of the other side and keeping them under control. The first of the abovementioned dimensions, 'lack of relative impact in the interpersonal relationships' refers to the individual's tendency to manipulate other individuals and events for their own goals, and the second dimension, 'lack of concern regarding the general code of ethics', refers to individual holding their own interests the highest while not refraining from lying and cheating in order to attain those interests. The third dimension is called the 'lack of psychopathology', which refers to the individual's tendency to be in contempt against and humiliate other individual(s). The fourth and the final dimension is the 'low ideological commitment' and refers to the lack of commitment and loyalty to friendships and private life and inability to maintain interpersonal relationships in the long term. However, the 
abovementioned model also drew some criticism since it only emphasized the negative characteristics of Machiavellianism (Deluga, 2001). In this context, Kessler and his colleagues (2010) defined the Machiavellian personality traits as the tendency to perform some manipulations in necessary conditions by an individual, who is a member of an organization, in order to attain their goals/targets. The differentiating point between the model suggested by Kessler and his colleagues (2010) and the model of Christie and Geis (1970) is the perspective that perceives the individuals with Machiavellian personality traits are not individuals that are absolutely bad, emotionless or cheating, but instead, they manipulate and cheat for organizational purposes and when faced with situations that present an advantage.

In the management and organizational research literature, it is argued that the individuals that exhibit Machiavellian personality traits can exhibit the personality attitudes at a high and a low level (McHoskey, 2001). In this context, the individuals that are stated to have the highest level of Machiavellian personality traits are in more of a tendency to establish authority over their environments, desire to control those within their social environments more and exhibit a higher tendency to take risk when compared to those with low level of Machiavellian personality traits (McHoskey, 2001; Allsopp et al., 1991; Dingler and Brown, 1987). In a similar manner, the individuals that are stated to have a higher level of Machiavellian personality traits were determined to be more successful in surviving and becoming successful in an environment where the competition is strong (Corzine, 1997; Austin et al., 2007). In this context, it can be argued that the individuals with such personality traits can be seen more commonly in organizations in today's competitive world.

The studies in the literature regarding Machiavellianism generally handle the concept in conjunction with other subjects of organizational behavior such as the big five personality model and other personality traits (Lee and Ashton, 2014; Allsopp et al.,1991), emotional intelligence (Austin et al., 2007), work performance, control focus, work satisfaction, narcissism, perception of leadership, and equality (Mudrack, 1990; McHoskey, 1995; Drory and Gluskinos, 1980; Gable and Topol, 1987; Heisler and Gemmill, 1977; Solar and Bruehl, 1971; Gable and Dangello, 1994; Russel, 1974; Özsoy and Ardıç, 2017; Demirtaş and Biçkes, 2014; Lopes and Fletcher, 2004), and it is accepted as an important tool for examining the reflection of the employee's personality on the organization.

\subsubsection{Big Five Personality Traits}

It can easily be said that the personality traits reveal themselves in every context that the individual socializes in and are one of the most important factors that affect their behavior. In relation to the concept of personality that is subject to various studies and typologies in the literature, it can be mentioned that one of the approaches that has been subject to many studies because of reasons such as its comprehensiveness and explanatory power is the 'Big Five Personality Model' (BFPM), and that this approach is commonly used in other behavioral sciences as well as organizational research literature.

Goldberg (1990) emphasizes that all dimensions developed in his study regarding the personality traits can be gathered under BFPM and the model is an umbrella concept regarding this framework. In this context, the big five personality traits approach (Goldberg, 1990; McCrea and Costa, 2006) essentially handles the relationship between the individual's personality traits and the human behavior in a systematic manner, and is comprised of agreeableness, extraversion, neuroticism, conscientiousness and openness to development sub-dimensions (Costa and McCrae, 1995).

Accordingly, the individuals with agreeableness personality traits exhibit positive traits such as openness to cooperation, flexibility and kindness, compassion and self-sacrifice (Moody, 2007), and the individuals with such personality traits rise to prominence within the social networks that they are a part of with their philanthropic traits (Clifton et. al., 2009). The individuals with extraversion personality trait are said to be generally positive, highly motivated, cheerful and energetic (Goldberg, 1992), and these individuals are able to quickly and effectively communicate with other individuals within the social network that they are included in (Clifton, 2009). Neuroticism, the third factor of the model, refers to the negative sides of the individuals such as emotional instability, bad temper, lack of self-confidence, pessimism and shyness (Costa and McCrae, 1992; 1995). The individuals that exhibit the fourth factor, conscientiousness, are seen as individuals that are responsible, trustworthy, honest, careful but also ambitious, success driven and determined (Costa and McCrae, 1992). In addition, it has been also argued that the individuals within a social network based on data who have a higher level of conscientiousness personality trait compared to others can form better friendships 
when compared to others (Jensen-Campbell and Malcolm, 2007). The final sub-dimension of BFPM is the openness to development, and individuals exhibiting this trait is described as individuals that are open to adventure, emotionality and new experiences (Costa and McCrae, 1995).

\subsection{Social Networks and Personality Traits}

It can be said that the social network studies in the literature of organizational studies are generally focused on the impact of the individual's behaviors on their position within the network structure and the quality of their relationships within the network (Wehrli, 2008). In other words, it can be said that the personality traits that they possess are in a relationship with the social network that they are a part of and their positions in the network, and the relatively dominant personality traits of the individual may have a certain impact on the location, position within the social network and the relationship qualities of the individual.

When the studies that are focused on the relationship between the individual's personality traits and their position within the social network structure in the literature of both the behavioral sciences and the management and operational research are examined, it can be seen that meaningful relationship patterns were identified especially within the last few years. In this context, the study of Aseendorpf and Wilpers (1998) on the social network comprised of peers can be given as an example for the studies in the behavioral sciences studies, and this study has determined that there is a relationship between the extraversion, sociability and shyness personality traits of the peers and the size of the social network and strong ties within the network. In their study, Casciaro (1998) states that there is a meaningful relationship between the individual's extraversion personality trait and the centrality score in a social network that is comprised of friendships. In a similar manner, the study by Kalish and Robins (2006) mentions that the neuroticism personality trait can be seen commonly in the open social networks that have many structural gaps and strong network relationships. Klein and his colleagues (2004) argue that the neuroticism personality traits of the individuals that are within a network structure based on friendship and their centrality scores within the network structure have a negative and meaningful relationship, however, the neuroticism personality traits of the individuals that are within a network structure based on solidarity and their centrality scores within the network structure have a positive and meaningful relationship.

The studies within the management sciences field regarding the subject generally discussed the employees' personality traits and their positions within the network structure. For instance, Baer's study (2010) examines whether there is a relation between the creativity levels of the actors in the works carried out within the organization and the size of the network structure that the actor is a part of, the strength and variety of the network relationships and the openness to experience personality trait of the said actors. The study concluded that the creativity levels of the actors within network structures that have high variability and weak ties and whose openness to experience personality trait is dominant are higher than those with lower variability. The study of Pollet and his colleagues (2011) states that the extraversion personality trait is in a meaningful and positive relationship with the size of the network. In a similar manner, Neubert and Tagger (2004) also mention that the extraversion and openness to experience personality traits are in a positive and meaningful relationship with the centrality scores of the social network that the individuals are included in. In this context, the higher the level of openness to experience and extraversion personality traits of the individual that is included in the social network that is subject to the abovementioned study is, the higher the level of individual's centrality. Another study in relation to the personality and social networks has been carried out by Roberts and his colleagues (2008), and it identified that the individuals with high level of extraversion personality trait in a social network were relatively better in the team support. In their meta-analysis study concerning the impact of the personality traits and the positions of the individuals in a social network on the business performance and career success, Fang and his colleagues (2015) identified that the personality traits and the positions of the individuals in a social network are more impactful on the business performance and career success when compared to the brokerage position of the in degree centrality within the social network.

There are also studies in the literature arguing that the social networks would not always provide individuals with positive returns (Bizzi, 2013). Bizzi (2013) argues in their study that if the actor that fills the structural gaps in a network structure and assumes the role of the bridge exhibits ambitious and jealous personality traits, then the actor may damage the group climate. 
Starting out from the abovementioned findings, it can be argued that the personality traits of an actor that assumes the role of a bridge / broker between the actors that do not have connection to each other in a network structure may have impact on the actor gaining their position within the network. In a broader sense, it can be said that an actor who assumes the role of brokerage within a certain social network may utilize the information and control advantages that they acquired due to their position, and this can be explained through the personality traits of the actor. When the abovementioned situation is examined in terms of actors with high level of Machiavellian personality traits, it is argued that the said actors have a tendency to establish their authority over their environments and have a desire to keep the other actors within their environments under control (Rim, 1966). In this context, it can be said that the individuals with high level of Machiavellian personality traits have a tendency to utilize the social relationships that they have in favor of themselves, similar to those who assume the role of broker. In other words, it can be argued that the personality traits that the individuals already possess are distinctive element regarding the role of the actors within the social network. In that vein, actors with dominant Machiavellian personality traits can be said to occupy the brokerage roles in the network structures due to such personality traits that they possess, and it is argued that there may be a meaningful relationship between the Machiavellian personality traits and the brokerage roles. In other words, it can be said that the attitudes stipulated by the brokerage role within the network structure and the Machiavellian personality traits may complement each other. However, the argument that the actors that have personality traits that refer to the relatively positive personality attitudes such as the agreeableness, extraversion or responsibility, the sub-dimensions of the big five personality traits may have a higher number of connections when compared to the other actors due to their positive attitudes, and therefore, they are positioned in a central location within the network could very well be a correct deduction.

Considering the aforesaid, it can be said that there is a relationship between the personality traits of the individuals within an organization and the social network structures that they are a part of. In a broader sense, this study examines the fact the personality traits of the individuals that are members of a network may have an impact on whether they are located at a central location in the social network or on some roles such as assuming the brokerage role by function as a bridge while filling the gaps between the actors that do not have a connection with each other. In this context:

Resarch Question 1: Is there a relationship between the personality traits of the actors that are located within a social network (the big five personality traits and Machiavellian personality attitudes) and their centrality degrees within the social network?

Resarch Question 2: Is there a relationship between the personality traits of the actors that are located within a social network (the big five personality traits and Machiavellian personality attitudes) and their brokerage roles within the social network? 


\section{Methodology}

\subsection{Research Model and Research Question}

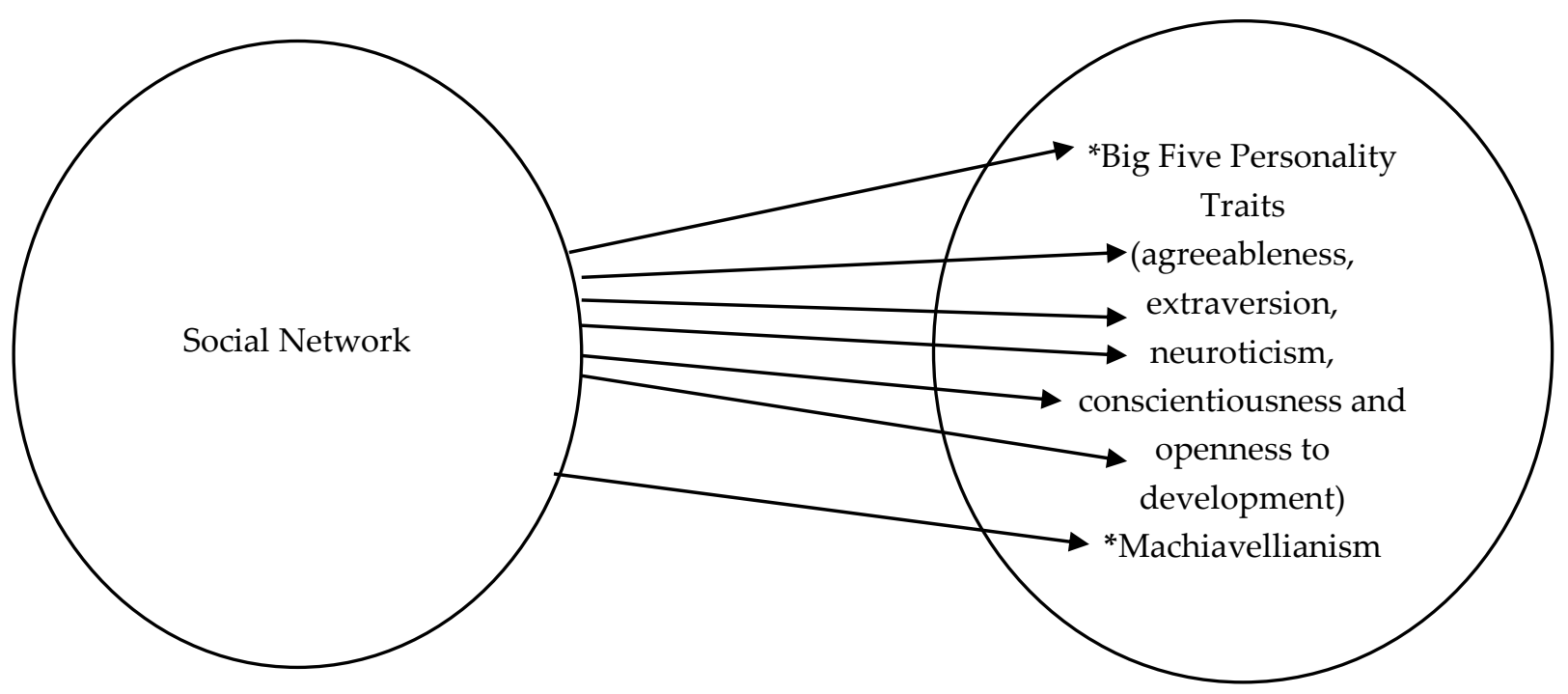

Resarch Question 1: Is there a relationship between the personality traits of the actors that are located within a social network (the big five personality traits and Machiavellian personality attitudes) and their centrality degrees within the social network?

Resarch Question 2: Is there a relationship between the personality traits of the actors that are located within a social network (the big five personality traits and Machiavellian personality attitudes) and their brokerage roles within the social network?

\subsection{Sample}

The sample identified for the studies in the management and organizational research literature that utilize the social network analysis methods must also comprise the research universe since the social network map is specific to the sample itself. In other words, due to fact that the samples in the network analysis research are specific to the selected network, the research has to include all the members of this network. Therefore, the network structure of the research has to be limited with the members of the given network. In this context, the sample of the study is comprised of 73 individuals that work in the same unit of a public institution located in Ankara.

\subsection{Data Collection Tools}

A list that includes the names and surnames of the network actors was formed in order to collect the social network data. The question of "Can you tell us if you have a social relationship with the names provided in the list?" was asked to the participants through the method of face to face interviews and by referring to the name and surname of the individuals that were members of the organization and were within the network, and "Yes, I have." and "No, I do not have" answers were received as feedback. A $73^{*} 73$ matrix was created in the UCINET 6.0 software for the said relationships, and the actors that were in a social relationship were assigned ' 1 ', and that were not in a social relationship were assigned ' $O$ '. The real identities of the actors were kept confidential during the research, and they were assigned codes such as 'A1,....,A73'. The centrality analysis, which refers to the number of connections between the actors within the network (in degree centrality - number of connections from others to the subject actor), and the betweenness analysis, which describes the brokerage role between two actors within close proximity, has been carried out via the matrix.

This network, in which the interaction between the personality traits of an actor that is included in a social network structure based on data and their position in the same network is examined, Machiavellian personality attitudes scales was first applied in order to identify the personality traits of the actors. Accordingly, the scale that was comprised of 71 expressions during its first inception was defined as Mach I, 
and the same scale that has been divided into Machiavellian and non-Machiavellian expressions was called as Mach II. The version that lowered the amount abovementioned 71 expressions to 20 expressions, which were believed to best represent the Machiavellian personality traits, was defined as Mach IV. In this context, this study utilized the Mach-IV scale, developed by Christie and Geis (1970) and adapted into Turkish by Demirtaş and Biçkes (2014), in order to identify the Machiavellian personality trait levels of the actors. In the Likert scale that is comprised of 20 expressions and range between the scores of " 1 (absolutely agree)" and " 5 (absolutely disagree)", 10 expressions were used to measure the Machiavellian personality behaviors and the other 10 expressions were comprised of expressions that do not reflect the Machiavellian personality behaviors. Measurement for the Machiavellian expressions were directly carried out by taking the scores, but a reverse scoring was carried out for the non-Machiavellian questions. Christie and Geis (1970) found the Cronbach Alpha value of the Mach IV scale to be 0.79, and Demirtaş and Biçkes (2014) has established the reliability value of the scale that is adapted into Turkish as 0.75 .

The Big Five Inventory that was developed by Benet-Martinez (1988) was used to identify another variable of the study, the big five personality traits. The scale is comprised of 44 clauses, and it was adapted into Turkish by Sümer and Sümer (2005). Upon the adaptation study, the reliability values of the scale for openness to experience, conscientiousness, agreeableness, extraversion and neuroticism were identified respectively as $0.72,0.67,0.60,0.73$, and 0.68 . The dependent variable of the study, the values gathered from the social network analysis, were entered into the SPSS 21 package software together with the values obtained from the personality scales, which comprised the independent variables, and their correlation and regression analyses were carried out.

\subsection{Findings}

The social network analysis was the first analysis in this study, which examines the impact of the personality traits of an individual on the centrality and brokerage positions of the individual within the social network. In this context, the top five actors that have the highest centrality and betweenness values are presented in Table 2 , and the centrality diagram is presented in Table 1.

Table 1. Centrality and Betweenness Scores

\begin{tabular}{|l|c|l|c|}
\hline \multicolumn{2}{|c|}{ Centrality (In Degree) } & \multicolumn{2}{c|}{ Betweenness } \\
\hline Actor14 & 123.4 & Actor29 & 179.4 \\
\hline Actor10 & 115.6 & Actor53 & 155.0 \\
\hline Actor43 & 100.0 & Actor64 & 147.0 \\
\hline Actor36 & 95.7 & Actor2 & 130.8 \\
\hline Actor51 & 81.4 & Actor46 & 100.0 \\
\hline
\end{tabular}


Figure 1. Betweenness Social Network Diagram

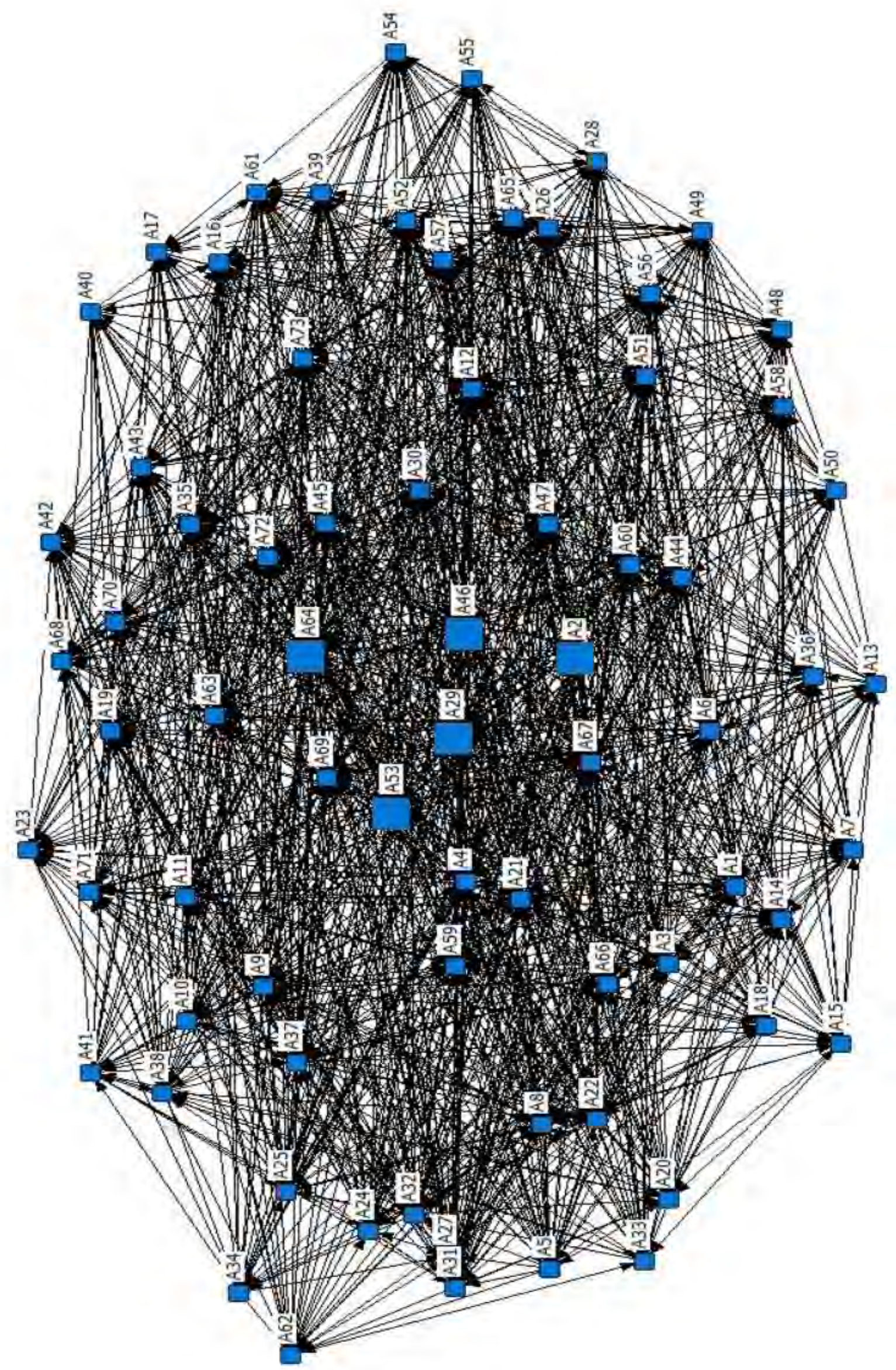


When Figure 1, which shows the betweenness connections between the members of the social network, is examined, it can be seen that the Actor 29 is the central broker actor in the network. It can be said that the A46, A53, A2 and A64 actors are located close to the center, right next to A29. On the other hand, it can be said that the actors coded A62, A34, A54 and A55 have the least amount of connections regarding the brokerage activities within the network and are located in the periphery of the network.

The scores obtained from the social network analysis and the personality scales were entered in the SPSS 21 software, their correlation and regression analysis were carried out regarding the identification of the intervariable relationship, and the results are presented in Table 3 and Table 4.

Table 2. Inter-Variable Correlation Analysis

\begin{tabular}{|c|c|c|}
\hline & Centrality & Betweenness \\
\hline Machiavellianism & .024 & $.255^{*}$ \\
\hline Extraversion & -.173 & .053 \\
\hline Agreeableness & $.303^{* *}$ & -.120 \\
\hline Responsibility & -.024 & .058 \\
\hline Openness to Experience & .098 & .045 \\
\hline Neuroticism & $-.243^{*}$ & $.318^{* *}$ \\
\hline
\end{tabular}

${ }^{* *} \mathrm{p}<0.01{ }^{*} \mathrm{p}<0.05(\mathrm{~N}=73)$

The centrality degrees of the actor's personality traits and then the betweenness values were examined in the correlation table that describe the relationship between the dependent variable of the research, the social networks, and the independent variable of the research, personality traits (Machiavellian and the Big Five).

In this context, when the Table 3 is examined for the identification of the relationship between the personality traits and the centrality scores, no meaningful relationship between the centrality position, which describes the number of connections that an actor has within the network that they are part of, and the Machiavellian personality traits could be established. On the other hand, a positive and meaningful relationship $(0.303$ $\mathrm{p}<0.01$ ) was established between the agreeableness dimension of the big five personality traits and the actor's centrality values. In this framework, it was identified that the individuals with high level of agreeableness personality trait, which refers to their positive characteristics such as openness to cooperation, kindness, compassion, self-sacrifice and philanthropism, are positioned at the center of the network having the highest number of connections in a social network structure based on data. A negative and meaningful relationship ($0.243 \mathrm{p}<0.05$ ) between the centrality degrees of the actors within the networks that they are located in and the neurotic personality trait, which is another dimension of the big five personality traits and refers to the personality traits such as emotional instability, bad temper, insecurity, pessimism.

When relationship between the betweenness scores, which refer to the actor that is the bridge / acts as a broker between the actors that in close proximity of each other within the network, and the personality traits are examined within the scope of the goals of the research, a positive and meaningful relationship $(0.255 \mathrm{p}<0.05)$ was identified between the Machiavellian personality traits of the individual and their brokerage positions, and this result is quite remarkable. In a similar manner, another remarkable point is the fact that the betweenness scores of the actors also have a positive and meaningful relationship $(0.318 p<0.01)$ with the neuroticism, which is one of the sub-dimensions of the big five personality traits.

Table 3. Inter-Variable Regression Analysis

\begin{tabular}{|c|c|c|}
\hline & Centrality & Betweenness \\
\cline { 2 - 3 } & $\mathbf{R}^{2}$ & $\mathbf{R}^{2}$ \\
\hline Machiavellianism & .008 & .240 \\
\hline Extraversion & .030 & .205 \\
\hline Agreeableness & .270 & .186 \\
\hline Responsibility & .092 & .085 \\
\hline Openness to Experience & .098 & .001 \\
\hline Neuroticism & .043 & .300 \\
\hline
\end{tabular}


According to Table 4, it can be said that the Machiavellian personality traits explain the $25 \%$ of the brokerage variable for the actor within the social network, and the remaining $75 \%$ can be explained by other variables. The second independent variable of the research, the sub-dimension of the big five personality traits, agreeableness personality trait is found out to be explaining the $27 \%$ of the actor's centrality within the network, and the neuroticism is found out to be explaining $30 \%$ of the centrality.

\section{Conclusion and Discussion}

The personality traits of individuals are the most fundamental factors that influence their social lives, and the social networks that the actor is a part of can be defined as one such factor. This study is based on the examination of whether the Machiavellian and the big five (extraversion, agreeableness, responsibility, openness to experience and neuroticism) personality traits of the individuals affect the positions of the actors within the social network that they are a part of. The study first evaluated whether there was a relationship between the aforesaid personality traits of the actors and the in degree centrality scores, which refer to the number of incoming connections to the actor from other actors within the structure that they are a part of. As a result of the quantitative and social network analyses, no meaningful relationship was identified between the Machiavellian personality traits of an actors and their central positioning within a network based on data.

A negative and meaningful relationship $(-0.243 \mathrm{p}<0.05)$ between the centrality degrees of the actors and the neurotic personality trait, which is another dimension of the big five personality traits; and a positive and meaningful relationship $(0.303 \mathrm{p}<0.01)$ between the agreeableness dimension and the actor's centrality values was established. In this framework, the actors with high level of agreeableness personality trait, which refers to the flexible, kind, affectionate and philanthropic personality traits, were identified as the actors that are located in the center and that have the highest number of positive network connections from other actors within the network. On the other hand, actors with the neurotic personality trait, which refers to the pessimism, negativism, bad temper and emotional instability states, can be qualified as actors that have the least amount of connections from other actors.

The study secondly examined whether there was a relationship between the personality traits of the actors and their brokerage roles, which refers to the actors being a bridge between the actors within the same network that do not have any connection and that are in close proximity. In this framework, a positive and meaningful relationship was identified between the Machiavellian personality traits and the brokerage positions of the actors. This result bears a quite remarkable characteristic. It was previously mentioned through the structural gaps theory, which refers to the actors that fill the gap / connection between the actors within a social network structure that do not have any connection / interaction with each other and that assume the role of a bridge, that the broker actor had the advantage of possessing the information circulating within the network, and furthermore, controlling the same information (Burt et. al., 1998). In addition, the actor who assumes the role of the broker within the network also took advantage of the structural gaps within the network structure and assumed the role of bridge between these gaps, and they had the chance to control the information from both sides (Burt, 2010). In this context, it was stated that the broker actor is relatively ahead of others in terms of accessing the information and acquiring some advantages for the benefit of themselves or the organization when compared to the other actors within the network (Gargiuli and Benassi, 2000). When the personality traits of Machiavellian individuals, which are inclined towards cheating in order to attain their personal goals, directing others for their own benefits, and focused towards power and success, are coupled with the power acquired from the brokerage role of the actor, this can bring about unwanted consequences in the eyes of the organization.

The negative and meaningful relationship between the brokerage roles of the actors and the agreeableness trait, which is one of the sub-dimensions of the big five personality traits, identified through the study is also considered to be a remarkable result. Thus, within the scope of the study, it was identified that while the actors within a network structure commonly preferred to establish relationships with actors that have agreeableness personality trait, the individuals with Machiavellian personality traits were prominent for the function of brokerage/bridge between the actors that do not have a connection with each other instead of those with agreeableness personality trait.

Limitations of The Study 


\section{P. Fayganoğlu 13/4 (2021) 3435-3452}

There are a few limitations in this study that must be mentioned. Firstly, the sample in the studies on social network analysis is specific to the selected network, the results of the research should be evaluated within this context and constraints. Since the social network data obtained within the scope of the study is completely specific to the individuals in the network, this constraint should be taken into account when evaluating the results of the study. The second limitation of the study is that only big five and machiavellianism are taken as the personality traits of the individuals in the study.

\section{Directions for Future Research}

This study, which examines the relationship between the personality traits of the individuals that are social entities and their positions within the social network structures that they are a part of, is considered to provide unique contributions to the literature in terms of the variables it utilized and results of its analyses, and it is anticipated that this study can illuminate the future studies regarding the subject. In this context, it is considered that in future studies, considering the relationships between different personality traits or other organizational behavior variables and social network connections in the literature will contribute to the literature. In addition, it is considered that future studies that will be carried out by considering a larger network with different organizational behavior variables can provide original contributions to the literature.

Practical Implications

It has been mentioned above that one of the most important factors that shape the organizational behavior elements in the organization and ultimately affect the organizational outputs is the personality traits of individuals. The personality traits of an actors can also be considered as one of the issues that will affect their social network ties and its structure. Some of the positions (centrality, brokerage etc.) of the actors in the social network constitute a source of power for them in some issues within the organization. From this point of view, revealing the social network structure in the organization will benefit the managers in many ways. It is considered that the identification of informal groups within the organization and especially the identification of the actors in important positions in the network are important for the manager to retain the power elements.

\section{References}

Allsopp, J., Eysenck, H. J., and Eysenck, S. B. G. (1991). Machiavellianism as a component in psychoticism and extraversion. Personality and Individual Differences, 12(1), 29-41.

Asendorpf, J. B., and Wilpers, S. (1998). Personality effects on social relationships. Journal of Personality and Social Psychology, 74(6), 1531-1544.

Ashton, M. C. (1998). Personality and job performance: The importance of narrow traits. The International Journal of Industrial, Occupational and Organizational Psychology and Behavior, 19(3), 289-303.

Austin, E. J., Farrelly, D., Black, C., and Moore, H. (2007). Emotional intelligence, Machiavellianism and emotional manipulation: Does EI have a dark side?. Personality and individual differences, 43(1), 179-189.

Baer, M. (2010). The strength-of-weak-ties perspective on creativity: A comprehensive examination and extension. Journal of applied psychology, 95(3), 592.

Benet-Martinez, V. and John, O. P. (1998). Los cinco grandes across cultures and ethnic groups: Multitraitmultimethod analyses of the Big Five in Spanish and English." Journal of Personality and Social Psychology, 75(3), 729-750.

Bizzi, L. (2013). The dark side of structural holes: A multilevel investigation. Journal of management, 39(6), 15541578 .

Blickle, G. 1996. Personality traits, learning stratigies, and performance. European Journal of personality, 10(5), 337-352.

Bourdieu, P. (1986). The force of law: Toward a sociology of the juridical field. Hastings LJ, 38, 805.

Burt, R. S., Jannotta, J. E., and Mahoney, J. T. (1998). Personality correlates of structural holes. Social Networks, 20, $63-87$. 


\section{P. Fayganoğlu 13/4 (2021) 3435-3452}

Burt, R. S. (2004). Structural holes and good ideas. American journal of sociology, 110(2), 349-399.

Burt, R. S. (2005). Brokerage and closure: An introduction to social capital. Oxford university press.

Burt, R. S. (2010). Neighbor networks: Competitive advantage local and personal.

Oxford University Press.

Casciaro, T. (1998). Seeing things clearly: Social structure, personality, and accuracy in social network perception. Social Networks, 20(4), 331-351. doi:10.1016/S0378-8733(98)00008-2

Christie, R., \& Geis F.L. (1970). Studies in Machiavellianism. New York Academic Pres, New York, N.Y:10-34.

Clifton, A., Turkheimer, E. and Oltmanns, T. F. (2009). Personality disorder in social networks: Network position as a marker of interpersonal dysfunction. Social Networks, 31(1), 26-32. doi:10.1016/j.socnet.2008.08.003

Colbert, A. E., Barrick, M. R., and Bradley, B. H. (2014). Personality and leadership composition in top management teams: Implications for organizational effectiveness. Personnel Psychology, 67(2), 351-387.

Coleman, J. S. (1988). Social capital in the creation of human capital. American journal of sociology, 94, S95-S120.

Coolidge, F. L., Becker, L. A., DiRito, D. C., Durham, R. L., Kinlaw, M. M., and Philbrick, P. B. (1994). On the relationship of the five-factor personality model to personality disorders: Four reservations. Psychological Reports, 75(1), 11-21.

Corzine, J. B. (1997). Machiavellianism and management: A review of single-nation studies exclusive of the USA and cross-national studies. Psychological reports, 80(1), 291-304.

Costa, P. T., and McCrae, R. R. (1995). “Domains and facets: Hiyerarchical personality assessment using the revised neo personality inventory." Journal of Personality Assessment, 64 (1), 21-50.

Deluga, R. J. (2001). American presidential Machiavellianism: Implications for charismatic leadership and rated performance. The leadership quarterly, 12(3), 339-363.

Demirtas, O:, and Biçkes, D. M. (2014). Makyavelizm'in Olumsuz Durumları Ifşa Etme Niyeti Uzerindeki Etkisi: Bir Alan Calıssması. The Journal Of Industrial Relations \& Human Resources, 16(2), 98-112.

DeNeve, K. M., and Cooper, H. (1998). The happy personality: A meta-analysis of 137 personality traits and subjective well-being. Psychological bulletin, 124(2), 197.

Diener, E., Suh, E. M., Lucas, R. E., and Smith, H. L. (1999). Subjective well-being: Three decades of progress. Psychological bulletin, 125(2), 276.

Diener, E., Lucas, R. E., and Oishi, S. (2002). Subjective well-being: The science of happiness and life satisfaction. Handbook of positive psychology, 2, 63-73.

Dingler-Duhon, M., and Brown, B. B. (1987). Self-disclosure as an influence strategy: Effects of Machiavellianism, androgyny, and sex. Sex Roles, 16(3-4), 109-123.

Drory, A., and Gluskinos, U. M. (1980). Machiavellianism and leadership. Journal of Applied Psychology, 65(1), 81.

Elovainio, M., Kivimäki, M., Vahtera, J., Virtanen, M., and Keltikangas-Järvinen, L. (2003). Personality as a moderator in the relations between perceptions of organizational justice and sickness absence. Journal of vocational behavior, 63(3), 379-395.

Erdheim, J., Wang, M., and Zickar, M. J. (2006). Linking the Big Five personality constructs to organizational commitment. Personality and individual differences, 41(5), 959-970.

Erkuş, A. (2010). Çok boyutlu lider-izleyici etkileşiminde kişilik özelliklerinin ve güç kaynaklarinin rolü. Atatürk Üniversitesi İktisadi ve İdari Bilimler Dergisi, 25(1), 127-152.

Fang, R., Landis, B., Zhang, Z., Anderson, M. H., Shaw, J. D., and Kilduff, M. (2015). Integrating personality and social networks: A meta-analysis of personality, network position, and work outcomes in organizations. Organization Science, 26(4), 1243-1260. 


\section{P. Fayganoğlu 13/4 (2021) 3435-3452}

Farrukh, M., Ying, C. W., and Mansori, S. (2017). Organizational commitment: an empirical analysis of personality traits. Journal of Work-Applied Management.

Fehr, B., Samsom, D., and Paulhus, D. L. (1992). The construct of Machiavellianism: Twenty years later. in, CD Spielberger ve JN Butcher (Eds.), Advances in personality assessment, 9: 77-116.

Forrester, W. R. \& Tashchian, A. (2010). Effects of personality on attitudes toward academic group work. “American Journal of Business Education (AJBE), 3(3), 39-46.

Furnham, A., and Cheng, H. (1997). Personality and happiness. Psychological Reports, 80(3), 761-762.

Furnham, A., Eracleous, A., \& Chamorro-Premuzic, T. (2009). Personality, motivation and job satisfaction: Hertzberg meets the Big Five. Journal of managerial psychology.

Gable, M., and Topol, M. T. (1987). Job satisfaction and Machiavellian orientation among department store executives. Psychological Reports, 60(1), 211-216.

Gable, M., and Dangello, F. (1994). Locus of control, Machiavellianism, and managerial job performance. The Journal of Psychology, 128(5), 599-608.

Gargiulo, M., and Benassi, M. (2000). Trapped in your own net? Network cohesion, structural holes, and the adaptation of social capital. Organization science, 11(2), 183-196.

Geis, F. L., ve Moon, T. H. (1981). Machiavellianism and deception. Journal of personality and social psychology, 41(4), 766.

Goldberg LR. (1990). An alternative "description of personality": The Big Five factor structure. Journal of Personality and Social Psychology, 59,1216-1229.

Goldberg, L. R. (1992). The development of markers for the Big-Five factor structure. Psychological assessment, 4(1), 26.

Grams, W. C., and Rogers, R. W. (1990). Power and personality: Effects of Machiavellianism, need for approval, and motivation on use of influence tactics. The Journal of General Psychology, 117(1), 71-82.

Granovetter, M. S. (1973). The strength of weak ties. American journal of sociology, 78(6), 1360-1380.

Granovetter, M. (1983). The strength of weak ties: A network theory revisited. Sociological theory, 201-233.

Gulati, R., and Gargiulo, M. (1999). Where do interorganizational networks come from?American journal of sociology, 104(5), 1439-1493.

Guterman, S. S. (1970). The Machiavellians: A social psychological study of moral character and organizational milieu. Lincoln: University of Nebraska Press.

Hagedoorn, J., Roijakkers, N.and Van Kranenburg, H. (2006). Inter-Firm R\&D Networks: the Importance of Strategic Network Capabilities for High-Tech Partnership Formation. British Journal of Management, 17: 39-53.

Heisler, W. J., and Gemmill, G. R. (1977). Machiavellianism, job satisfaction, job strain, and upward mobility: Some cross-organizational evidence. Psychological Reports, 41(2), 592-594.

Henle, C. A. (2005). Predicting workplace deviance from the interaction between organizational justice and personality. Journal of managerial issues, 247-263.

Hoffman, L. R. (1959). Homogeneity of member personality and its effect on group problem-solving. The Journal of Abnormal and Social Psychology, 58(1), 27.

Jensen-Campbell, L. A., and Malcolm, K. T. (2007). The importance of conscientiousness in adolescent interpersonal relationships. Personality and Social Psychology Bulletin, 33(3), 368-383.

Jones, D. N., and Paulhus, D. L. (2009). Machiavellianism. NY. Guilford Press

Judge, T. A., Bono, J. E., and Locke, E. A. (2000). Personality and job satisfaction: The mediating role of job characteristics. Journal of applied psychology, 85(2), 237. 


\section{P. Fayganoğlu 13/4 (2021) 3435-3452}

Kalish, Y., and Robins, G. (2006). Psychological predispositions and network structure: The relationship between individual predispositions, structural holes and network closure. Social Networks, 28(1), 56-84. doi:10.1016/j.socnet.2005.04.004

Karkoulian, S., Messarra, L., and Sidani, M. (2009). Correlates of the bases of power and the big five personality traits: an empirical investigation. In Allied Academies International Conference. Academy of Organizational Culture, Communications and Conflict. Proceedings 14(1), 7.

Kell, H. J., and Motowidlo, S. J. (2012). Deconstructing Organizational Commitment: Associations Among Its Affective and Cognitive Components, Personality Antecedents, and Behavioral Outcomes. Journal of Applied Social Psychology, 42(1), 213-251.

Kessler, S. R., Bandelli, A. C., Spector, P. E., Borman, W. C., Nelson, C. E., and Penney, L. M. (2010). Reexamining Machiavelli: A three-dimensional model of Machiavellianism in the workplace. Journal of Applied Social Psychology, 40(8), 1868-1896.

Kim, Y., Choib T. Y., Yanb, T., Dooleyb, K. (2011). Structural investigation of supply networks: A social network analysis approach. Journal of Operations Management, 29: 194-211.

Kalish, Y., and Robins, G. (2006). Psychological predispositions and network structure: The relationship between individual predispositions, structural holes and network closure. Social networks, 28(1), 56-84.

Klein, K. J., Lim, B.-C., Saltz, J. L., and Mayer, D. M. (2004). How Do they Get there? An examination of the antecedents of centrality in team networks. The Academy of Management Journal, 47(6), 952. doi:10.2307/20159634.

Kraatz, M. S. (1998). Learning by association? Interorganizational networks and adaptation to environmental change. Academy of management journal, 41(6), 621-643.

Kogan, N., and Wallach, M. A. (1964). Risk taking: A study in cognition and personality. NY, Holt.

Lee, K., \& Ashton, M. C. (2014). The dark triad, the big five, and the HEXACO model. Personality and Individual Differences, 67, 2-5.

Lelord, F. \& Andre C. (1996). Zor Kişilikler'le Yaşamak (Çev. R Madenci), İstanbul: İletişim Yayınları.

Levenson, M. R. (1990). Risk taking and personality. Journal of personality and social psychology, 58(6), 1073.

Lopes, J., and Fletcher, C. (2004). Fairness of impression management in employment interviews: A crosscountry study of the role of equity and Machiavellianism. Social Behavior and Personality: an international journal, 32(8), 747-768.

Lu, L., and Hu, C. H. (2005). Personality, leisure experiences and happiness. Journal of happiness studies, 6(3), 325-342.

McCrae, R. R., and Costa Jr, P. T. (1991). Adding Liebe und Arbeit: The full five-factor model and wellbeing. Personality and social psychology bulletin, 17(2), 227-232.

McHoskey, J. (1995). Narcissism and machiavellianism. Psychological reports, 77(3), 755-759.

McHoskey, J. W., Worzel, W., and Szyarto, C. (1998). Machiavellianism and psychopathy. Journal of personality and social psychology, 74(1), 192.

McHoskey, J. W. (2001). Machiavellianism and personality dysfunction. Personality and Individual Differences, 31(5), 791-798.

Montag, I., and Levin, J. (1994). The five-factor personality model in applied settings. European Journal of Personality, 8(1), 1-11.

Morrison, K. A. (1997). How franchise job satisfaction and personality affects performance, organizational commitment, franchisor relations, and intention to remain. Journal of Small Business Management, 35(3), 39.

Mudrack, P. E. (1990). Machiavellianism and locus of control: A meta-analytic review. The Journal of Social Psychology, 130(1), 125-126. 
Moody, M. C. (2007). Adaptive behavior in intercultural environments: The relationship between cultural intelligence factors and big five personality traits. (Doctoral dissertation, George Washington University).

Mount, M., Ilies, R., and Johnson, E. (2006). Relationship of personality traits and counterproductive work behaviors: The mediating effects of job satisfaction. Personnel psychology, 59(3), 591-622

Neubert, M. J., and Taggar, S. (2004.) Pathways to informal leadership: The moderating role of gender on the relationship of individual differences and team member network centrality to informal leadership emergence. The Leadership Quarterly, 15(2), 175-194. doi:10.1016/j.leaqua.2004.02.006

Newbury-Birch, D., and Kamali, F. (2001). Psychological stress, anxiety, depression, job satisfaction, and personality characteristics in preregistration house officers. Postgraduate medical journal, 77(904), 109111.

Nicholson, N., Soane, E., Fenton-O'Creevy, M., and Willman, P. (2005). Personality and domain-specific risk taking. Journal of Risk Research, 8(2), 157-176.

O'Connor, P. J., and Athota, V. S. (2013). The intervening role of agreeableness in the relationship between trait emotional intelligence and Machiavellianism: Reassessing the potential dark side of EI. Personality and Individual Differences, 55(7), 750-754.

O'Neill, T. A., and Kline, T. J. (2008). Personality as a predictor of teamwork: A business simulator study. North American Journal of Psychology, 10(1).

Özsoy, E., and Ardiç, K. (2017). Karanlık üçlü'nün (narsisizm, makyavelizm ve psikopati) iş tatminine etkisinin incelenmesi. Yonetim ve Ekonomi, 24(2), 391.

Parkes, K. R. (1994). Personality and coping as moderators of work stress processes: Models, methods and measures. Work \& Stress, 8(2), 110-129.

Paunonen, S. V., and Ashton, M. C. (2013). On the prediction of academic performance with personality traits: A replication study. Journal of Research in Personality, 47(6), 778-781.

Peterson, R. S., Smith, D. B., Martorana, P. V., and Owens, P. D. (2003). The impact of chief executive officer personality on top management team dynamics: One mechanism by which leadership affects organizational performance. Journal of applied Psychology, 88(5), 795.

Podolny, J. M. (2001). Networks as the pipes and prisms of the market. American journal of sociology, 107(1), 3360.

Pollet, T. V., Roberts, S. G. B., and Dunbar, R. I. M. (2011). Extraverts have larger social network layers. Journal of Individual Differences, 32(3), 161-169. doi:10.1027/1614-0001/a000048

Quick, J. C., Quick, J. D., Nelson, D. L., and Hurrell Jr, J. J. (1997). Preventive stress management in organizations. American Psychological Association.

Rim, Y. (1966). Machiavellianism and decisions involving risk. British Journal of Social and Clinical Psychology, 5(1), 30-36.

Robbins, S. P. (1999). Layoff-survivor sickness: A missing topic in organizational behavior. Journal of Management Education, 23(1), 31-43.

Roberts, B. W., Kuncel, N. R., Shiner, R., Caspi, A., and Goldberg, L. R. (2007). The power of personality: The comparative validity of personality traits, socioeconomic status, and cognitive ability for predicting important life outcomes. Perspectives on Psychological science, 2(4), 313-345.

Roberts, S., Wilson, R., Fedurek, P., and Dunbar, R. (2008). Individual differences and personal social network size and structure. Personality and Individual Differences, 44(4), 954-964. doi:10.1016/j.paid.2007.10.033

Russell, G. W. (1974). Machiavellianism, locus of control, aggression, performance and precautionary behaviour in ice hockey. Human Relations, 27(9), 825-837. 


\section{P. Fayganoğlu 13/4 (2021) 3435-3452}

Sargut, S. (2006). Sosyal Sermaye: Yapının sunduğu bir olanak mı, yoksa bireyin amaçlı eylemi mi. Akdeniz İ̈BF Dergisi, 6(12), 1-13.

Shi, J., Lin, H., Wang, L., and Wang, M. (2009). Linking the big five personality constructs to organizational justice. Social Behavior and Personality: an international journal, 37(2), 209-222.

Shih, M. L., Lin, S. H., Hsiao, S. H., Huang, L. M., Chiu, C. C., and Chen, K. Y. (2009). The study of the correlation among personality traits, leadership competence and organizational performance. WSEAS Transactions on Business and Economics, 1(6), 11-20.

Sikalieh, D., and Mkoji, D. (2012). The influence of personality dimensions on organizational performance. International Journal of Humanities and Social Science, 17 (2): 184-195.

Srivastava, S. (2013). Job satisfaction and organizational commitment relationship: Effect of personality variables. Vision, 17(2), 159-167.

Solar, D., and Bruehl, D. (1971). Machiavellianism and locus of control: Two conceptions of interpersonal power. Psychological Reports, 29(3_suppl), 1079-1082.

Sözen, C. and Gürbüz, S. (2012). Örgütsel Aglar. In H. C. Sözen ve H. N. Basım, (Ed.) Örgüt Kuramları (1) (301327). Istabul: Beta Basım ve Yayım Dağtım.

Sumer, N., and Sumer, H. C. (2005). Bes faktor kisilik ozellikleri olcegi. Unpublished research project.

Wakefield, R. L. (2008). Accounting and machiavellianism. Behavioral Research in Accounting, 20(1), 115-129.

Wehrli, S. (2008). Personality on social network sites: An application of the five factor model. Zurich: ETH Sociology (Unpublished Working Paper No. 7)

Yelboğa, A. (2006). Kişilik özellikleri ve iş performansı arasındaki ilişkinin incelenmesi. ISGUC The Journal of Industrial Relations and Human Resources, 8(2), 196-217.

Zuckerman, M., and Kuhlman, D. M. (2000). Personality and risk-taking: common bisocial factors. Journal of personality, 68(6), 999-102 